\title{
(2) OPEN ACCESS \\ Severity of COVID-19 and survival in patients with rheumatic and inflammatory diseases: data from the French RMD COVID-19 cohort of 694 patients
}

\author{
FAI $^{2} R /$ /SFR/SNFMI/SOFREMIP/CRI/IMIDIATE consortium and contributors
}

\begin{abstract}
Handling editor Josef S Smolen

- Additional material is published online only. To view, please visit the journal online (http://dx.doi.org/10.1136/ annrheumdis-2020-218310).

Filière des Maladies Autoimmunes et Autoinflammatoires Rares (FAI2R); Hôpital Huriez, CHU Lille, Univ. Lille, Lille, France
\end{abstract}

\section{Correspondence to} FAI ${ }^{2} \mathrm{R} / \mathrm{SFR} / \mathrm{SNFMI/SOFREMIP/}$ CRI/IMIDIATE consortium and contributors;

eric.hachulla@chru-lille.fr

Received 16 June 2020 Revised 6 October 2020 Accepted 8 October 2020 Published Online First 2 December 2020

\section{Check for updates}

(C) Author(s) (or their employer(s)) 2021. Re-use permitted under CC BY-NC. No commercial re-use. See rights and permissions. Published by BMJ.

\section{ABSTRACT \\ Objectives There is little known about the impact of SARS-CoV-2 on patients with inflammatory rheumatic and musculoskeletal diseases (iRMD). We examined epidemiological characteristics associated with severe disease, then with death. We also compared mortality between patients hospitalised for COVID-19 with and without IRMD. Methods Individuals with suspected RMDD-COVID-19 were included in this French cohort. Logistic regression models adjusted for age and sex were used to estimate adjusted ORs and $95 \%$ Cls of severe COVID-19. The most significant clinically relevant factors were analysed by multivariable penalised logistic regression models, using a forward selection method. The death rate of hospitalised patients with iRMD-COVID-19 (moderate- severe) was compared with a subset of patients with non-iRMD-COVID-19 from a French hospital matched for age, sex, and comorbidities.}

Results Of 694 adults, 438 (63\%) developed mild (not hospitalised), 169 (24\%) moderate (hospitalised out of the intensive care unit (ICU) and 87 (13\%) severe (patients in ICU/deceased) disease. In multivariable imputed analyses, the variables associated with severe infection were age $(\mathrm{OR}=1.08,95 \% \mathrm{Cl}: 1.05-1.10)$, female gender ( $\mathrm{OR}=0.45,95 \% \mathrm{Cl}: 0.25-0.80)$, body mass index (OR=1.07, 95\% Cl: $1.02-1.12)$, hypertension ( $\mathrm{OR}=1.86,95 \% \mathrm{Cl}: 1.01-3.42)$, and use of corticosteroids ( $O R=1.97,95 \% \mathrm{Cl}: 1.09-3.54)$, mycophenolate mofetil $(\mathrm{OR}=6.6,95 \% \mathrm{Cl}: 1.47-29.62)$ and rituximab $(\mathrm{OR}=4.21,95 \% \mathrm{Cl}: 1.61-10.98)$. Fiftyeight patients died (8\% (total) and 23\% (hospitalised)). Compared with 175 matched hospitalised patients with non-iRMD-COVID-19, the OR of mortality associated with hospitalised patients with iRMD-COVID-19 was 1.45 (95\% Cl: 0.87-2.42) ( $n=175$ each group).

Conclusions In the French RMD COVID-19 cohort, as already identified in the general population, older age, male gender, obesity, and hypertension were found to be associated with severe COVID-19. Patients with RMD on corticosteroids, but not methotrexate, or tumour necrosis factor alpha and interleukin-6 inhibitors, should be considered as more likely to develop severe COVID-19. Unlike common comorbidities such as obesity, and cardiovascular or lung diseases, the risk of death is not significantly increased in patients with iRMD.

Trial registration number ClinicalTrials.gov Registry (NCT04353609).

\section{INTRODUCTION}

In December 2019, COVID-19, caused by the SARS-CoV-2, emerged from Wuhan, China. ${ }^{1}{ }^{2}$ Beginning 1 February 2020, France had a total of

\section{Key messages}

What is already known about this subject?

- As stated by recent European League Against Rheumatism guidelines, there is no evidence that patients with inflammatory rheumatic and musculoskeletal diseases (iRMD) are at higher risk of SARS-CoV-2 infection than individuals without iRMD, nor have a worse prognosis with a diagnosis of COVID-19.

- In patients with iRMD, glucocorticoid therapy at doses $\geq 10 \mathrm{mg} /$ day of equivalent (prednisone) is associated with higher odds of hospitalisation and anti-tumour necrosis factor (TNF) with decreased odds.

What does this study add?

- Patients with iRMD are more likely to develop severe SARS-CoV-2 infection when they have comorbidities already identified as risk factors of severe COVID-19 infection in the general population, such as older age, male gender, obesity, and hypertension.

- Regardless of the dose, corticosteroids were associated with severe infection, whereas methotrexate, and TNF $\alpha$ and interleukin-6 (IL-6) inhibitors were not. Anti-TNF use was associated with less frequent hospitalisation.

- When matched for common comorbidities, the population with iRMD may not have more frequent death compared with the population with non-iRMD.

How might this impact on clinical practice or future developments?

- In addition to common risk factors for severe SARS-CoV-2 infection, patients with iRMD on any dose of corticosteroid should be considered as particularly fragile and at high risk for developing severe disease, whereas patients on methotrexate and TNF $\alpha$ and IL-6 inhibitors are not.

- A potential risk of more severe COVID-19 in patients with interstitial lung disease or treated by rituximab justifies further research.

six confirmed cases and was under nationwide lockdown by $17 \mathrm{March}^{3}$ and now has just over 344000 confirmed cases and over 30000 deaths (as of 5 October 2020), ${ }^{4}$ with a mean age 68 years for hospitalised patients and 79 years for those who 
died. ${ }^{5}$ Stay-at-home restrictions in France decreased hospitalisations nearly 11 -fold ${ }^{5}$; however, there remains an urgent need for safe, effective COVID-19 therapies.

There is a concern that patients undergoing immunosuppressive therapy for inflammatory rheumatic and musculoskeletal diseases (iRMD) could be more vulnerable to SARS-CoV-2 infection and hospitalisation than the general population, particularly in those patients with comorbidities such as diabetes, chronic obstructive pulmonary disease, and renal failure. ${ }^{67}$ Several recent studies in patients with $\mathrm{RMMD}^{8-10}$ and inflammatory bowel diseases (IBD) ${ }^{11}$ suggested an increased risk for hospitalisation and severe disease when using glucocorticoids, although no effect on severity or mortality was found with biological diseasemodifying anti-rheumatic drug (DMARD) use. A decreased risk for severe COVID-19 was suggested in such populations with respect to anti-tumour necrosis factor alpha (TNF $\alpha)$ drugs. ${ }^{11} 12$ Although these studies indicate that the incidence of immunemediated inflammatory disease among patients with COVID-19 was consistent with the general population and not associated with worse outcomes, population size was a major limitation. Recent European League Against Rheumatism (EULAR) guidelines suggested that patients with RMD are not at greater risk for developing SARS-CoV-2 infection or more severe disease, ${ }^{13}$ but as additional information is obtained through ongoing research and clinical trials, recommendations are continually updated.
Taken together, to provide optimal care and ensure positive clinical outcomes in patients with RMD who contracted SARS-CoV-2 infection, it is imperative to understand how these diseases, their comorbidities and the use of immunotherapies may affect progression to severe COVID-19 or death. The primary objective of the current study, by analysing a French cohort of 694 patients with iRMD and COVID-19, was to investigate the frequency of severe infection and predictive factors associated with disease severity. The secondary objectives were to identify predictive factors associated with death and to compare the death rate in patients with moderate to severe COVID-19 with and without RMD.

\section{METHODS}

\section{Study design and patients}

This is an observational, multicentre, French national cohort study in which patients of all ages with confirmed iRMD (table 1) and highly suspected/confirmed diagnosis of COVID-19 were enrolled. All eligible patients/representatives were informed. The study was performed in accordance with the principles of the Declaration of Helsinki. Positive diagnosis of COVID-19 included biological confirmation (PCR/serology), presence of ground-glass opacities in CT scan, or anosmia or sudden ageusia in the absence of rhinitis or nasal obstruction, or typical clinical

Table 1 Descriptive table of diagnoses according to severity of COVID-19

\begin{tabular}{|c|c|c|c|c|c|c|}
\hline Classification, n (\%) & $\begin{array}{l}\text { Overall } \\
(n=694)\end{array}$ & $\begin{array}{l}\text { Patients with } \\
\text { mild infection } \\
(n=438)\end{array}$ & $\begin{array}{l}\text { Patients with } \\
\text { moderate } \\
\text { infection } \\
(n=169)\end{array}$ & $\begin{array}{l}\text { Patients } \\
\text { with severe } \\
\text { infection } \\
(n=87)\end{array}$ & $\begin{array}{l}\text { Survivors } \\
(\mathrm{n}=617)\end{array}$ & $\begin{array}{l}\text { Non-survivors } \\
(\mathrm{n}=58)\end{array}$ \\
\hline \multicolumn{7}{|l|}{ Chronic inflammatory arthritis } \\
\hline Rheumatoid arthritis & $213(30.7)$ & $129(29.5)$ & $55(32.5)$ & $29(33.3)$ & $187(30.3)$ & $20(34.5)$ \\
\hline Axial and peripheral spondyloarthritis & $165(23.8)$ & $135(30.8)$ & $25(14.8)$ & $5(5.8)$ & $161(26.1)$ & $1(1.7)$ \\
\hline Psoriatic arthritis & $70(10.1)$ & $52(11.9)$ & $12(7.1)$ & $6(6.9)$ & 64 (10.4) & $3(5.2)$ \\
\hline Non-systemic idiopathic juvenile arthritis & $2(0.3)$ & $2(0.5)$ & 0 & 0 & $2(0.3)$ & 0 \\
\hline Other inflammatory arthritis & $14(2.0)$ & $7(1.6)$ & $5(3.0)$ & $2(2.3)$ & $13(2.1)$ & $1(1.7)$ \\
\hline \multicolumn{7}{|l|}{ Autoinflammatory diseases } \\
\hline Still's disease & $5(0.7)$ & $1(0.2)$ & $2(1.2)$ & $2(2.3)$ & $4(0.7)$ & $1(1.7)$ \\
\hline Periodic fever syndromest & $15(2.2)$ & $8(1.8)$ & $5(3.0)$ & $2(2.3)$ & $13(2.1)$ & $2(3.5)$ \\
\hline Systemic idiopathic juvenile arthritis & $3(0.4)$ & $2(0.5)$ & $1(0.6)$ & 0 & $3(0.5)$ & 0 \\
\hline Other autoinflammatory diseases & $4(0.6)$ & $2(0.5)$ & $1(0.6)$ & $1(1.2)$ & $3(0.5)$ & $1(1.7)$ \\
\hline \multicolumn{7}{|l|}{ Vasculitis } \\
\hline Giant cell arteritis and polymyalgia rheumatica & $30(4.3)$ & $8(1.8)$ & $10(5.9)$ & $12(13.8)$ & $21(3.40)$ & $9(15.5)$ \\
\hline Behcet's disease & $7(1.0)$ & $3(0.7)$ & $3(1.8)$ & $1(1.2)$ & $6(1.0)$ & $1(1.7)$ \\
\hline Vasculitis associated with cytoplasmic antineutrophil antibodies & $17(2.5)$ & $4(0.9)$ & $4(2.4)$ & $9(10.4)$ & $10(1.6)$ & $7(12.1)$ \\
\hline Takayasu's arteritis & $1(0.1)$ & $1(0.2)$ & 0 & 0 & $1(0.2)$ & 0 \\
\hline Other vasculitis (including Kawasaki's disease) & $10(1.4)$ & $5(1.1)$ & $5(3.0)$ & 0 & $9(1.5)$ & 0 \\
\hline \multicolumn{7}{|l|}{ Systemic autoimmune diseases } \\
\hline Systemic lupus erythematosus & $46(6.6)$ & $32(7.3)$ & $11(6.5)$ & $3(3.5)$ & $42(6.8)$ & $2(3.5)$ \\
\hline Systemic sclerosis & $25(3.6)$ & $17(3.9)$ & $6(3.6)$ & $2(2.3)$ & $23(3.7)$ & $2(3.5)$ \\
\hline Primary Sjögren syndrome & $17(2.5)$ & $7(1.6)$ & $7(4.1)$ & $3(3.5)$ & $15(2.4)$ & $2(3.5)$ \\
\hline Inflammatory myopathy (including dermatomyositis, polymyositis) & $12(1.7)$ & $6(1.4)$ & $3(1.8)$ & $3(3.5)$ & $8(1.3)$ & $3(5.2)$ \\
\hline Undifferentiated connective tissue disease & $3(0.4)$ & $3(0.7)$ & 0 & 0 & $1(0.2)$ & 0 \\
\hline Mixed connective tissue disease & $4(0.6)$ & 0 & $3(1.8)$ & $1(1.2)$ & $3(0.5)$ & $1(1.7)$ \\
\hline \multicolumn{7}{|l|}{ Other } \\
\hline Sarcoidosis & $15(2.2)$ & $6(1.4)$ & $5(3.0)$ & $4(4.6)$ & $12(1.9)$ & $2(3.5)$ \\
\hline Eye inflammation (including uveitis) & $3(0.4)$ & $2(0.5)$ & $1(0.6)$ & 0 & $3(0.5)$ & 0 \\
\hline $\operatorname{lgG}_{4}$-related disease & $3(0.4)$ & $1(0.2)$ & $1(0.6)$ & $1(1.2)$ & $3(0.5)$ & 0 \\
\hline Other & $10(1.4)$ & $5(1.1)$ & $4(2.4)$ & $1(1.2)$ & $10(1.6)$ & 0 \\
\hline
\end{tabular}

${ }^{*}$ Total number of survivors and non-survivors as presented excludes 19 patients whose status at day 21 was unknown at the time of data cut-off.

tIncludes TNF receptor-associated periodic syndrome, cryopyrin-associated periodic syndromes, familial Mediterranean fever, and mevalonate kinase deficiency.

TNF, tumour necrosis factor. 
signs of COVID-19 (cough, fever, nose/throat symptoms, digestive symptoms without any other diagnosis, influenza syndrome in a patient with recent close contact with a known COVID-19 positive patient). Patients were informed about the objective of the study, and patient consent was obtained for the use of medical data, which was carried out according to French law and good clinical practices. Approval from an ethics committee was not required according to French law. ${ }^{14}$ The study was performed in compliance with MR-004, ${ }^{15}$ received permission from Lille University Hospital, was declared to the Commission Nationale de l'Informatique et des Libertés (reference DEC20-107).

To compare the death rate resulting from moderate to severe COVID-19 between the population with iRMD and non-iRMD, the Lille University Hospital COVID-19 Research Network (LICORNE) was used. This includes 335 patients with COVID-19 hospitalised in the Lille University Hospital between 24 February and 17 April 2020 for moderate to severe COVID-19. Among them, 256 patients were selected as potential controls, to match to the moderate to severe (hospitalised/ intensive care unit (ICU)/death) patients from the French RMD COVID-19 cohort. All patients with iRMD and control patients received care from the same national health system.

\section{Data collection}

All cases of highly suspected/confirmed patients with iRMDCOVID-19 were reported retrospectively. The individual data regarding iRMD diagnosis/specific treatments were captured from rheumatologists, internal medicine physicians or paediatric physicians via one national data entry portal. All treating physicians are members of the FAI ${ }^{2} \mathrm{R} / \mathrm{SFR} / \mathrm{SNFMI/SOFREMIP/}$ CRI/IMIDIATE consortium. Data collected from the patient's medical record included demographics and clinical information such as onset of iRMD and current treatments, presence of comorbidities, details of COVID-19 diagnosis, management and outcome with an evaluation of the vital status assessment at least 21 days after the first clinical sign of COVID-19. The main diagnosis was selected for analysis, which justified the management and the choice of treatments. To ensure secure transmission of data, information was collected from the investigating physician via the electronic case report form or a provided file. Data cut-off was on 18 May 2020. Before freezing, the final database was monitored to collect missing data, validate the evolution of COVID-19, remove duplicate or erroneous reports, and check data consistency. All deaths were verified by Eric Hachulla and Christophe Richez to ensure complete data were obtained and if missing, to collect data directly by contacting the physician.

\section{Outcomes}

The primary endpoint was the frequency of severe infection in patients with iRMD and predictive factors associated with disease severity. The severity of COVID-19 was assessed and classified according to the care needed for each patient: mild=ambulatory; moderate $=$ hospitalised out of ICU; and severe $=\mathrm{ICU}$ or deceased. The secondary objectives were to identify predictive factors associated with death and to compare the death rate in patients with moderate to severe COVID-19 with and without inflammatory iRMD.

\section{Statistical analysis}

Categorical variables were expressed as numbers (percentage) and quantitative variables as mean \pm SD. Comparisons of severe versus mild or moderate patients and survivors versus nonsurvivors were made using logistic regression models (in case of cell frequency $<5$, a penalised logistic regression (Firth method $)^{14}$ was used), with and without adjustment on prespecified factors (age and sex). No statistical comparisons were done for categorical variables with a frequency $<10$ in the overall sample. Odds ratios (ORs) and their $95 \%$ confidence intervals (CIs) were calculated as effect size. Factors associated with severity and hospitalisation status in the age-sex adjusted analyses $(p<0.05)$ were introduced into multivariable penalised logistic regression models with a forward stepwise selection procedure (entrance criterion $=0.05$ ) to limit overfitting. To avoid case deletion in multivariable analyses, missing data for candidate predictors were imputed by multiple imputations using the regression-switching approach (chained equations, $\mathrm{n}=10$ imputations)..$^{16}$ The imputation procedure was performed under the missing-at-random assumption using all candidate predictors, with logistic regression (binary, ordinal or multinomial) models for categorical variables. Rubin's rules were used to combine the estimates derived from multiple imputed data sets. ${ }^{17}$ Multivariate analysis was performed in available cases (without missing data on candidate predictors) as sensitivity analysis. French RMD COVID-19 cases and LICORNE controls were matched for age, sex, and comorbidities (cardiac disease, diabetes, hypertension, body mass index/BMI, and renal failure) using a propensity score estimation, calculated using a multivariable logistic regression model. Choice of these confounders was based on published literature. ${ }^{18} 19$ The two groups were matched (1:1) using an optimal algorithm with calliper width of $0.2 \mathrm{SD}$ of logit for propensity score. ${ }^{2021}$ To evaluate the bias reduction, absolute standardised differences were calculated before and after matching. An absolute standardised difference $>10 \%$ was interpreted as a meaningful difference. ${ }^{22}$ OR for death (iRMD vs controls) was estimated using a mixed logistic regression. All statistical tests were performed at the two-tailed $\alpha$ level of 0.05 using SAS software, V.9.4.

\section{Patient and public involvement}

Patients were not directly involved in the design, recruitment, or conduct of the study.

\section{RESULTS}

\section{Patient characteristics}

We collected a total of 758 records and the final evaluation of COVID-19 severity (primary endpoint) was available for 694 patients (the 13 children were not included in the statistical analysis and are described separately). COVID-19 diagnosis was confirmed in 59\% of cases based on PCR or serology (408/694). Of those patients with confirmed COVID-19, approximately $47 \%(193 / 408)$ had a mild, $34 \%(138 / 408)$ moderate, and 19\% (77/408) severe infection. In the other patients, COVID-19 diagnosis was confirmed by typical CT scan in 6\% (46/694), anosmia/ageusia in 14\% (96/694), and typical clinical symptoms in $21 \%(144 / 694)$.

Patients were mainly women $(66.6 \%, 462 / 694)$ with a mean age of $56.1 \pm 16.4$ years, and $51.6 \%(358 / 694)$ were over the age of 55 years (figure 1). Seventy-one percent of the population had at least one comorbidity (492/694), with hypertension $(\mathrm{n}=182,26.3 \%)$, obesity with a BMI over $30 \mathrm{~kg} / \mathrm{m}^{2}(\mathrm{n}=146$, $21 \%)$, respiratory disease $(n=99,14.3 \%)$, and cardiovascular disease $(\mathrm{n}=85,12.3 \%)$ as the most common. Chronic inflammatory arthritis diseases were the most frequent diagnoses in the cohort $(66.9 \%, 464 / 694)$, mostly rheumatoid arthritis (RA) and spondyloarthritis, followed by systemic autoimmune diseases 


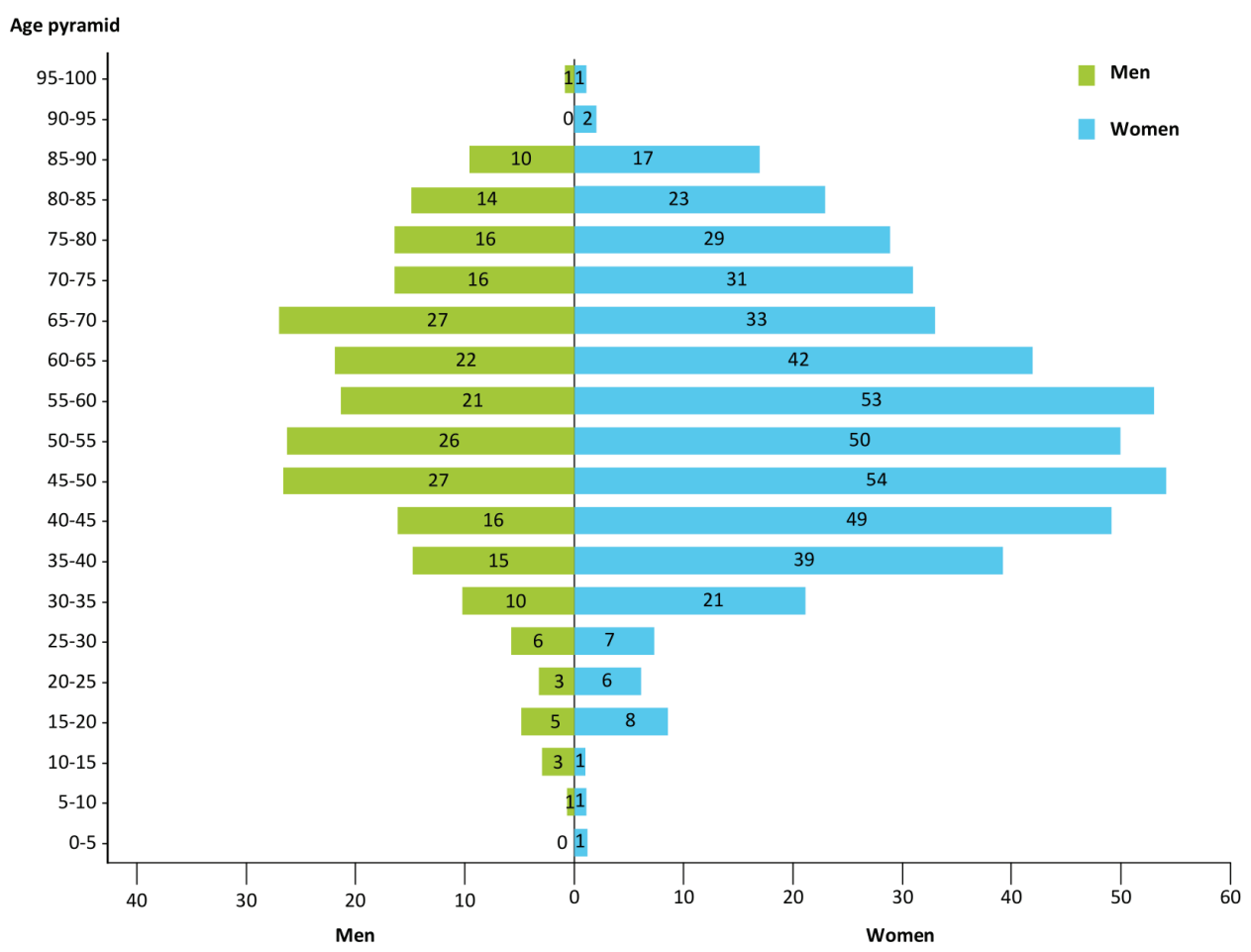

Figure 1 Age-pyramid including the 694 adult patients used in the statistical analysis as well as the 13 children.

(15.4\%, 107/694). A detailed description of all iRMD diagnoses included in the cohort is presented in table 1 .

\section{Development of severe disease}

The frequency of severe COVID-19 in patients with iRMD with confirmed or highly suspected diagnosis of symptomatic COVID-19 was 12.5\% (87/694). Age was a driver of disease severity, as only 11 patients between 18 and 54 years developed severe COVID-19, whereas this number increased to 20 in patients between 65 and 74 years (adjusted OR $(\mathrm{aOR})=6.46$, 95\% CI: 2.97-14.06), and to 45 in patients over 75 years $(\mathrm{aOR}=19.82,95 \% \mathrm{CI}:$ 9.69-40.52). There were no severe paediatric cases. When adjusted for age and sex, among the most common comorbidities correlated with severe disease were morbid obesity (BMI $\left.\geq 40 \mathrm{~kg} / \mathrm{m}^{2}\right)(\mathrm{aOR}=4.10,95 \% \mathrm{CI}$ : 1.28-13.11), diabetes $(\mathrm{aOR}=2.14,95 \% \mathrm{CI}: 1.12-4.12)$, and hypertension $(\mathrm{aOR}=2.30,95 \% \mathrm{CI}: 1.34-3.96)$. Interestingly, interstitial lung disease $(\mathrm{aOR}=2.87,95 \% \mathrm{CI}: 1.06-7.80)$ and chronic renal failure $(\mathrm{aOR}=3.22,95 \% \mathrm{CI}$ : $1.51-6.90)$ were also associated with disease severity. Severe disease was observed more frequently in patients with vasculitis $(\mathrm{aOR}=2.25,95 \% \mathrm{CI}$ : $1.13-4.41)$ and autoinflammatory diseases $(\mathrm{aOR}=7.88,95 \% \mathrm{CI}$ : 1.39-37.05), compared with patients with chronic inflammatory arthritis. These results are summarised in table 2. Morbid obesity, diabetes, hypertension, and chronic renal failure were still correlated with severe disease when the analysis was focused only on patients with PCR-confirmed COVID-19 (online supplemental table 1). While not significant, there was also an association with interstitial lung disease $(\mathrm{aOR}=2.64,95 \% \mathrm{CI}$ : 0.94-7.36). In the PCR-confirmed population, severe disease was still observed more frequently in patients with vasculitis $(\mathrm{aOR}=2.39,95 \% \mathrm{CI}: 1.14-4.98)$, compared with patients with chronic inflammatory arthritis.

Regarding treatments for iRMDs, more frequent severe disease was observed with the use of corticosteroids $(\mathrm{aOR}=2.25$, 95\% CI: 1.33-3.79), mycophenolate mofetil $(\mathrm{aOR}=7.67$,
95\% CI: 1.73-28.04) and rituximab $(\mathrm{aOR}=4.34$, 95\% CI: 1.77-10.63). It should be noted that use of TNF $\alpha$ blockers $(\mathrm{n}=202, \mathrm{aOR}=0.44,95 \% \mathrm{CI}: 0.19-1.04)$, interleukin-6 (IL-6) inhibitors $(\mathrm{n}=26, \mathrm{aOR}=0.63,95 \% \mathrm{CI}: 0.12-2.28)$, methotrexate $(\mathrm{n}=252, \mathrm{aOR}=0.63,95 \% \mathrm{CI}: 0.37-1.08)$ and hydroxychloroquine (HCQ) $(\mathrm{n}=57, \mathrm{aOR}=1.06,95 \% \mathrm{CI}: 0.31-2.96)$ were not associated with severe COVID-19 (table 3). When the same analysis was performed on the population with PCR-confirmed COVID-19, rituximab was still identified as a contributor to the development of severe disease $(\mathrm{aOR}=6.35$, 95\% CI: 2.23-18.11) (online supplemental table 2). However, there was no significant increase in the development of severe disease with the use of corticosteroids ( $\mathrm{aOR}=1.72,95 \% \mathrm{CI}$ : 0.98-3.04) nor significant decrease in the development of severe disease with the use of TNF blockers $(\mathrm{aOR}=0.42$, 95\% CI: 0.16-1.15).

Similar results were observed in patients with RA $(n=213)$ with respect to the severity of disease including age (aOR age $\geq 75=16.89$, 95\% CI: 4.90-88.60), hypertension $(\mathrm{aOR}=3.36$, $95 \% \mathrm{CI}: 1.23-8.60)$, and use of corticosteroids $(\mathrm{aOR}=2.57$, 95\% CI: $1.01-6.52)$ or rituximab $(\mathrm{aOR}=5.97,95 \% \mathrm{CI}: 1.18-$ 27.63) (online supplemental tables 3 and 4).

Results of the multivariable analysis are presented in table 4. Due to the number of events (87 patients with severe infection), the analysis was limited to no more than seven variables, which were selected based on clinical expertise. Older age $(\mathrm{OR}=1.08,95 \% \mathrm{CI}: 1.05-1.10)$, female gender $(\mathrm{OR}=0.45$, 95\% CI: 0.25-0.80), BMI (OR=1.07, 95\% CI: 1.02-1.12), hypertension $(\mathrm{OR}=1.86,95 \% \mathrm{CI}: 1.01-3.42)$, and use of corticosteroids $(\mathrm{OR}=1.97,95 \% \mathrm{CI}: 1.09-3.54)$, mycophenolate mofetil $(\mathrm{OR}=6.6,95 \% \mathrm{CI}: 1.47-29.62)$ and rituximab $(\mathrm{OR}=4.21,95 \% \mathrm{CI}: 1.61-10.98)$ were significantly associated with COVID-19 severity. Results of the imputed analysis are similar compared with the available case analysis (see table 4). 
Table 2 Association between demographic and clinical characteristics and severity of COVID-19

\begin{tabular}{|c|c|c|c|c|c|c|c|c|}
\hline & $\begin{array}{l}\text { All patients } \\
(n=694)\end{array}$ & $\begin{array}{l}\text { Patients with } \\
\text { mild infection } \\
\text { ( } n=438)\end{array}$ & $\begin{array}{l}\text { Patients with } \\
\text { moderate } \\
\text { infection } \\
(n=169)\end{array}$ & $\begin{array}{l}\text { Patients } \\
\text { with severe } \\
\text { infection } \\
(\mathrm{n}=87)\end{array}$ & OR $(95 \% \mathrm{Cl})^{*}$ & $P$ value & $\operatorname{aOR}(95 \% \mathrm{Cl})^{*} \dagger$ & $P$ valuet \\
\hline Age (years) & & & & & & $<0.001$ & & $<0.001$ \\
\hline $18-54$ & $336(48.4)$ & $268(61.2)$ & $57(33.7)$ & $11(12.6)$ & 1.00 (ref.) & - & 1.00 (ref.) & - \\
\hline $55-64$ & $138(19.9)$ & $95(21.7)$ & $32(18.9)$ & $11(12.6)$ & $2.56(1.08-6.05)$ & 0.032 & $2.58(1.09-6.12)$ & 0.032 \\
\hline $65-74$ & $107(15.4)$ & $52(11.9)$ & $35(20.7)$ & $20(23.0)$ & $6.79(3.14-14.71)$ & $<0.001$ & $6.46(2.97-14.06)$ & $<0.001$ \\
\hline$\geq 75$ & $113(16.3)$ & $23(5.3)$ & $45(26.6)$ & $45(51.7)$ & $19.55(9.62-39.73)$ & $<0.001$ & $19.82(9.69-40.52)$ & $<0.001$ \\
\hline Mean \pm SD & $56.1 \pm 16.4$ & $50.6 \pm 13.9$ & $61.8 \pm 16.1$ & $72.4 \pm 13.8$ & & & & \\
\hline Female gender & $462(66.6)$ & $309(70.6)$ & $109(64.5)$ & $44(50.6)$ & $0.46(0.29-0.73)$ & $<0.001$ & $0.45(0.27-0.75)$ & 0.002 \\
\hline \multicolumn{9}{|l|}{ Comorbiditiesł } \\
\hline Respiratory disease (all) & $99(14.3)$ & $53(12.2)$ & $25(14.8)$ & $21(24.1)$ & $2.15(1.25-3.71)$ & 0.006 & $1.61(0.87-2.99)$ & 0.13 \\
\hline Interstitial lung disease & $26(3.8)$ & $10(2.3)$ & $7(4.1)$ & $9(10.3)$ & $3.99(1.72-9.26)$ & 0.001 & $2.87(1.06-7.80)$ & 0.038 \\
\hline COPD & $28(4.0)$ & $14(3.2)$ & $6(3.6)$ & $8(9.2)$ & $2.96(1.26-6.95)$ & 0.013 & $1.08(0.42-2.76)$ & 0.88 \\
\hline Asthma & $52(7.5)$ & $32(7.3)$ & $14(8.3)$ & $6(6.9)$ & $0.90(0.37-2.18)$ & 0.82 & $1.24(0.46-3.33)$ & 0.67 \\
\hline Cardiac disease (all) & $85(12.3)$ & $22(5.0)$ & $31(18.3)$ & $32(36.8)$ & $6.06(3.61-10.18)$ & $<0.001$ & $1.78(0.97-3.28)$ & 0.064 \\
\hline Coronary heart diseases & $68(9.8)$ & $15(3.4)$ & $25(14.8)$ & $28(32.2)$ & $6.70(3.86-11.65)$ & $<0.001$ & $1.86(0.97-3.56)$ & 0.063 \\
\hline Stroke & $25(3.6)$ & $7(1.6)$ & $10(5.9)$ & $8(9.2)$ & $3.50(1.46-8.38)$ & 0.005 & $1.68(0.63-4.47)$ & 0.30 \\
\hline Diabetes & $62(9.0)$ & $12(2.8)$ & $29(17.2)$ & $21(24.1)$ & $4.38(2.44-7.85)$ & $<0.001$ & $2.14(1.12-4.12)$ & 0.022 \\
\hline Obesity & & & & & & 0.050 & & 0.043 \\
\hline$<30$ & $459(75.9)$ & $303(78.7)$ & $105(71.9)$ & $51(68.9)$ & 1.00 (ref.) & - & 1.00 (ref.) & - \\
\hline $30-39.9$ & $126(20.8)$ & 74 (19.2) & $35(24.0)$ & $17(23.0)$ & $1.25(0.69-2.25)$ & 0.46 & $1.47(0.76-2.82)$ & 0.25 \\
\hline$\geq 40$ & $20(3.3)$ & $8(2.1)$ & $6(4.1)$ & $6(8.1)$ & $3.43(1.26-9.32)$ & 0.016 & $4.10(1.28-13.11)$ & 0.017 \\
\hline Hypertension & $182(26.3)$ & $71(16.3)$ & $60(35.5)$ & $51(58.6)$ & $5.13(3.21-8.19)$ & $<0.001$ & $2.30(1.34-3.96)$ & 0.003 \\
\hline Cancer & $33(4.8)$ & $13(3.0)$ & $13(7.7)$ & $7(8.0)$ & $1.95(0.82-4.64)$ & 0.13 & $0.83(0.31-2.21)$ & 0.71 \\
\hline Chronic renal failure & $42(6.1)$ & $11(2.5)$ & $12(7.1)$ & $19(21.8)$ & 7.07 (3.66-13.65) & $<0.001$ & $3.22(1.51-6.90)$ & 0.003 \\
\hline $\begin{array}{l}\text { No. of patients with at least one } \\
\text { comorbidity }\end{array}$ & $492(71.1)$ & $274(62.8)$ & $136(80.5)$ & $82(94.3)$ & $7.80(3.11-19.54)$ & $<0.001$ & $3.52(1.35-9.17)$ & 0.010 \\
\hline Disease history§ & & & & & & $<0.001$ & & 0.023 \\
\hline Chronic inflammatory arthritis & $464(66.9)$ & $325(74.2)$ & $97(57.4)$ & $42(48.3)$ & 1.00 (ref.) & - & 1.00 (ref.) & - \\
\hline Autoinflammatory diseases & $12(1.7)$ & $5(1.1)$ & $4(2.4)$ & $3(3.4)$ & $3.66(0.89-12.07)$ & 0.053 & $7.88(1.39-37.05)$ & 0.014 \\
\hline Vasculitis & $65(9.4)$ & $21(4.8)$ & $22(13.0)$ & $22(25.3)$ & $5.14(2.80-9.32)$ & $<0.001$ & $2.25(1.13-4.41)$ & 0.020 \\
\hline Systemic autoimmune diseases & $122(17.6)$ & $73(16.7)$ & $35(20.7)$ & $14(16.1)$ & $1.33(0.69-2.45)$ & 0.38 & $1.64(0.80-3.25)$ & 0.17 \\
\hline
\end{tabular}

Values are presented as frequency (percentage) unless otherwise indicated.

*ORs were calculated for patients with severe infection, using patients with mild or moderate infection as reference.

tAdjusted for age and sex.

¥Two missing values for comorbidities except for obesity where 89 values are missing

$\S$ Penalised logistic regression (Firth method) was used due to low number of patients $(n<5)$ in an analysed group.

$\mathrm{aOR}$, adjusted OR; COPD, chronic obstructive pulmonary disease.

\section{Hospitalisation status}

Hospitalisation status of the whole population $(n=694)$ was also affected, and was more frequently related to older age (aOR age $\geq 75=15.51,95 \% \mathrm{CI}: 9.11-26.40$ ) as well as the presence of coronary heart disease $(\mathrm{aOR}=2.73,95 \% \mathrm{CI}$ : $1.40-5.30)$, diabetes $\quad(\mathrm{aOR}=5.37,95 \% \mathrm{CI}: 2.66-10.85)$, hypertension $(\mathrm{aOR}=1.99,95 \% \mathrm{CI}: 1.33-2.98)$, and chronic renal failure $(\mathrm{aOR}=2.76,95 \% \mathrm{CI}: 1.26-6.04)$ (online supplemental table 5). Use of corticosteroids (aOR=2.76, 95\% CI: 1.90-4.02) and TNF $\alpha$ inhibitors (aOR $=0.35,95 \%$ CI: $0.22-0.55$ ) also affected hospitalisation status and were harmful or protective, respectively (online supplemental table 6). Within the multivariable imputed analysis, age ( $\mathrm{OR}=1.05,95 \% \mathrm{CI}$ : $1.04-1.07)$, diabetes $(\mathrm{OR}=4.33$, 95\% CI: 2.07-9.07), BMI (OR=1.06, 95\% CI: $1.02-$ 1.10), use of corticosteroids ( $\mathrm{OR}=1.94,95 \% \mathrm{CI}: 1.24-3.05)$ and colchicine (OR=3.34, 95\% CI: 1.14-9.79) remain associated with a higher risk of hospitalisation. Use of TNF inhibitors $(\mathrm{OR}=0.55,95 \% \mathrm{CI}: 0.32-0.95)$ and female gender $(\mathrm{OR}=0.65$, 95\% CI: 0.43-0.99) were associated with less frequent hospitalisation (online supplemental table 7).

\section{Paediatric cases}

Thirteen patients were paediatric cases and are described in table 5 .

\section{Survival}

Fifty-eight patients in our cohort died, resulting in an overall death rate of $8.3 \%$, which corresponds to $22.6 \%$ of death in the hospitalised subgroup (58/256) (table 6). Of 335 patients in the LICORNE cohort (patients with non-RMD COVID-19), only 175 controls were matched for age, sex and comorbidities (cardiac disease, diabetes, hypertension, BMI and renal failure) (online supplemental table 8). By matching patients to the LICORNE cohort, a death rate of 25.1\% (95\% CI: 18.7-31.6) was observed in the French RMD COVID-19 compared with $18.9 \%$ (95\% CI: 13.1-24.7, respectively) with an OR of 1.45 (95\% CI: $0.87-2.42 ; n=175$ in each group). In the iRMD COVID-19 cohort, death was more frequent in patients aged $\geq 55$ years $(\mathrm{aOR}(55-64)=5.54,95 \% \mathrm{CI}: 1.62-23.13$; $\mathrm{aOR}(65-74)=6.70,95 \% \mathrm{CI}: 1.95-28.07$; $\mathrm{aOR} \quad(\geq 75)=59.02$, 95\% CI: 21.79-221.45), and with the presence of interstitial lung disease $(\mathrm{aOR}=3.82,95 \% \mathrm{CI}: 1.27-11.49)$, coronary heart disease $(\mathrm{aOR}=2.18,95 \% \mathrm{CI}: 1.05-4.53)$, diabetes $(\mathrm{aOR}=2.89,95 \% \mathrm{CI}$ : 
Table 3 Association between rheumatic disease treatments and severity of COVID-19

\begin{tabular}{|c|c|c|c|c|c|c|c|c|}
\hline & $\begin{array}{l}\text { All patients } \\
(n=694)\end{array}$ & $\begin{array}{l}\text { Patients with } \\
\text { mild infection } \\
(n=438)\end{array}$ & $\begin{array}{l}\text { Patients with } \\
\text { moderate } \\
\text { infection } \\
(n=169)\end{array}$ & $\begin{array}{l}\text { Patients } \\
\text { with severe } \\
\text { infection } \\
(n=87)\end{array}$ & OR $(95 \% \mathrm{CI})^{*}$ & $P$ value & aOR $(95 \% \mathrm{Cl})^{*} \dagger$ & $\begin{array}{l}P \\
\text { valuet }\end{array}$ \\
\hline \multicolumn{9}{|l|}{ Rheumatic or inflammatory disease treatments } \\
\hline Corticosteroid & $215(31.1)$ & $88(20.1)$ & $76(45.2)$ & $51(59.3)$ & $3.93(2.46-6.26)$ & $<0.001$ & $2.25(1.33-3.79)$ & 0.002 \\
\hline Daily prednisone $\geq 10 \mathrm{mg}$ or equivalent & $73(34.3)$ & $28(31.8)$ & $22(29.3)$ & $23(46.0)$ & $1.93(1.01-3.68)$ & 0.048 & $1.69(0.83-3.45)$ & 0.15 \\
\hline NSAIDs§ & $73(10.5)$ & $61(13.9)$ & $10(6.0)$ & $2(2.3)$ & $0.22(0.05-0.66)$ & 0.022 & $0.50(0.10-1.58)$ & 0.31 \\
\hline Colchicine & $24(3.5)$ & $12(2.7)$ & $8(4.8)$ & $4(4.7)$ & $1.56(0.48-4.09)$ & 0.41 & $3.18(0.77-11.24)$ & 0.090 \\
\hline Hydroxychloroquine§ & $57(8.2)$ & $40(9.1)$ & $13(7.7)$ & $4(4.7)$ & $0.56(0.18-1.37)$ & 0.26 & $1.06(0.31-2.96)$ & 0.91 \\
\hline Methotrexate & $252(36.4)$ & $164(37.4)$ & $62(36.9)$ & $26(30.2)$ & $0.73(0.45-1.19)$ & 0.20 & $0.63(0.37-1.08)$ & 0.096 \\
\hline Leflunomide & $27(3.9)$ & $19(4.3)$ & $8(4.8)$ & 0 & NA & NA & NA & NA \\
\hline Sulfasalazine & $9(1.3)$ & $5(1.1)$ & $4(2.4)$ & 0 & NA & NA & NA & NA \\
\hline Mycophenolate mofetil/ mycophenolic acid§ & $16(2.3)$ & $9(2.1)$ & $4(2.4)$ & $3(3.5)$ & $1.84(0.47-5.54)$ & 0.33 & $7.67(1.73-28.04)$ & 0.004 \\
\hline Azathioprine§ & $9(1.3)$ & $5(1.1)$ & $3(1.8)$ & $1(1.2)$ & NA & NA & NA & NA \\
\hline IgIV§ & $7(1.0)$ & $3(0.7)$ & $2(1.2)$ & $2(2.3)$ & NA & NA & NA & NA \\
\hline \multicolumn{9}{|l|}{ Biologics } \\
\hline Anti-TNF & $202(29.2)$ & $170(38.8)$ & $25(14.9)$ & $7(8.1)$ & $0.19(0.09-0.41)$ & $<0.001$ & $0.44(0.19-1.04)$ & 0.060 \\
\hline Anti-IL-6§ & $26(3.8)$ & $19(4.3)$ & $5(3.0)$ & $2(2.3)$ & $0.70(0.14-2.21)$ & 0.61 & $0.63(0.12-2.28)$ & 0.54 \\
\hline Rituximab & $34(4.9)$ & $16(3.7)$ & $7(4.2)$ & $11(12.8)$ & $3.72(1.74-7.93)$ & $<0.001$ & $4.34(1.77-10.63)$ & 0.001 \\
\hline Anti-IL-17a§ & $27(3.9)$ & $19(4.3)$ & $6(3.6)$ & $2(2.3)$ & $0.67(0.14-2.12)$ & 0.57 & $2.34(0.45-8.21)$ & 0.24 \\
\hline Anti-IL-1§ & $8(1.2)$ & $3(0.7)$ & $3(1.8)$ & $2(2.3)$ & NA & NA & NA & NA \\
\hline Abatacept§ & $18(2.6)$ & $10(2.3)$ & $7(4.2)$ & $1(1.2)$ & $0.59(0.07-2.39)$ & 0.55 & $0.37(0.04-1.80)$ & 0.31 \\
\hline JAK inhibitor§ & $21(3.0)$ & $13(3.0)$ & $4(2.4)$ & $4(4.7)$ & $1.84(0.56-4.91)$ & 0.27 & $1.94(0.54-5.98)$ & 0.28 \\
\hline Other biologic & $16(2.3)$ & $11(2.5)$ & $5(3.0)$ & 0 & NA & NA & NA & NA \\
\hline
\end{tabular}

Values are presented as frequency (percentage) unless otherwise indicated.

Not applicable (NA) when $<10 / 694$ patients or when 0 patients with severe infection.

*ORs were calculated for patients with severe infection, using patients with mild or moderate infection as reference.

†Adjusted for age and sex.

‡Two patients with missing information for treatments.

$\S$ Penalised logistic regression (Firth method) was used due to low number of patients $(n<5)$ in an analysed group.

aOR, adjusted OR; IgIV, immunoglobulin intravenous; IL, interleukin; NSAIDs, non-steroidal anti-inflammatory drugs; TNF, tumour necrosis factor.

1.39-6.02), hypertension $(\mathrm{aOR}=3.08$, 95\% CI: 1.56-6.08) or chronic renal failure $(\mathrm{aOR}=5.22,95 \% \mathrm{CI}: 2.22-12.31)$. In addition, systemic autoimmune diseases were more frequently associated with death $(\mathrm{aOR}=2.65,95 \% \mathrm{CI}: 1.15-5.95)$ compared with chronic inflammatory arthritis (table 6). Regarding treatments, use of corticosteroids ( $\mathrm{aOR}=2.64,95 \% \mathrm{CI}: 1.36-5.12)$, colchicine $(\mathrm{aOR}=8.21$, 95\%CI: 1.60-37.97), mycophenolate mofetil $(\mathrm{aOR}=14.20$, 95\% CI: $2.26-70.24)$ or rituximab $(\mathrm{aOR}=4.04$, 95\% CI: $1.35-$ 12.04) was associated with a higher frequency of death, whereas a reduced hazard was observed in patients taking methotrexate for iRMD $(\mathrm{aOR}=0.34,95 \% \mathrm{CI}: 0.16-0.70)$ (table 7$)$. Of note, the use of $\mathrm{TNF} \alpha$ or IL-6 inhibitors was not associated with death $(\mathrm{aOR}=0.74$,
95\% CI: $0.22-2.01$ and $\mathrm{aOR}=0.50,95 \% \mathrm{CI}: 0.05-2.38$, respectively). A detailed description of all fatalities is available in online supplemental table 9 .

\section{Treatments used in French patients with iRMD who contracted SARS-CoV-2 infection}

With respect to COVID-19-specific treatment used in the French iRMD-COVID-19 cohort, among the total population, $18.6 \%$ $(129 / 694)$ received antiviral or immunomodulating therapies, which increased to $30.2 \%$ (51/169) with moderate infection and $37.9 \%(33 / 87)$ with severe infection. HCQ, alone or in

Table 4 Multivariable analyses for disease severity

\begin{tabular}{|c|c|c|c|c|c|c|}
\hline \multirow[b]{2}{*}{ Variable } & \multicolumn{3}{|c|}{ Imputed analysis* $(n=694)$} & \multicolumn{3}{|c|}{ Available case analysis $(n=601)$} \\
\hline & $\mathrm{n} / \mathrm{N}$ & OR $(95 \% \mathrm{Cl})$ & $P$ value & $\mathrm{n} / \mathrm{N}$ & OR $(95 \% \mathrm{Cl})$ & $P$ value \\
\hline Age (years) & $87 / 694$ & $1.08(1.05-1.10)$ & $<0.001$ & $73 / 601$ & $1.08(1.05-1.10)$ & $<0.001$ \\
\hline Female gender & $44 / 462$ & $0.45(0.25-0.80)$ & 0.007 & $37 / 395$ & $0.43(0.24-0.78)$ & 0.005 \\
\hline BMI & $87 / 694$ & $1.07(1.02-1.12)$ & 0.006 & $73 / 601$ & $1.07(1.02-1.12)$ & 0.007 \\
\hline Hypertension & $51 / 182$ & $1.86(1.01-3.42)$ & 0.047 & $42 / 162$ & $1.83(0.99-3.37)$ & 0.054 \\
\hline Corticosteroids & $51 / 216$ & $1.97(1.09-3.54)$ & 0.024 & $45 / 188$ & $2.04(1.13-3.67)$ & 0.018 \\
\hline Mycophenolate mofetil/mycophenolic acid & $3 / 16$ & $6.60(1.47-29.62)$ & 0.014 & $3 / 14$ & $6.51(1.45-29.23)$ & 0.015 \\
\hline Rituximab & $11 / 34$ & $4.21(1.61-10.98)$ & 0.003 & $10 / 32$ & $4.60(1.75-12.11)$ & 0.002 \\
\hline
\end{tabular}

ORs were calculated using multivariable penalised logistic regression models (Firth method), using a forward selection method, with patients with mild or moderate infection as reference. Only variables selected by the model are presented. Full model included age, sex, interstitial lung disease, diabetes, BMI, hypertension, chronic renal failure, disease history, corticosteroids, mycophenolate mofetil/mycophenolic acid and rituximab.

$\mathrm{n} / \mathrm{N}$ indicated the number of events/number of cases.

${ }^{*}$ ORs and $p$ value were calculated after multiple imputations $(m=10)$ to handle missing data.

BMI, body mass index. 


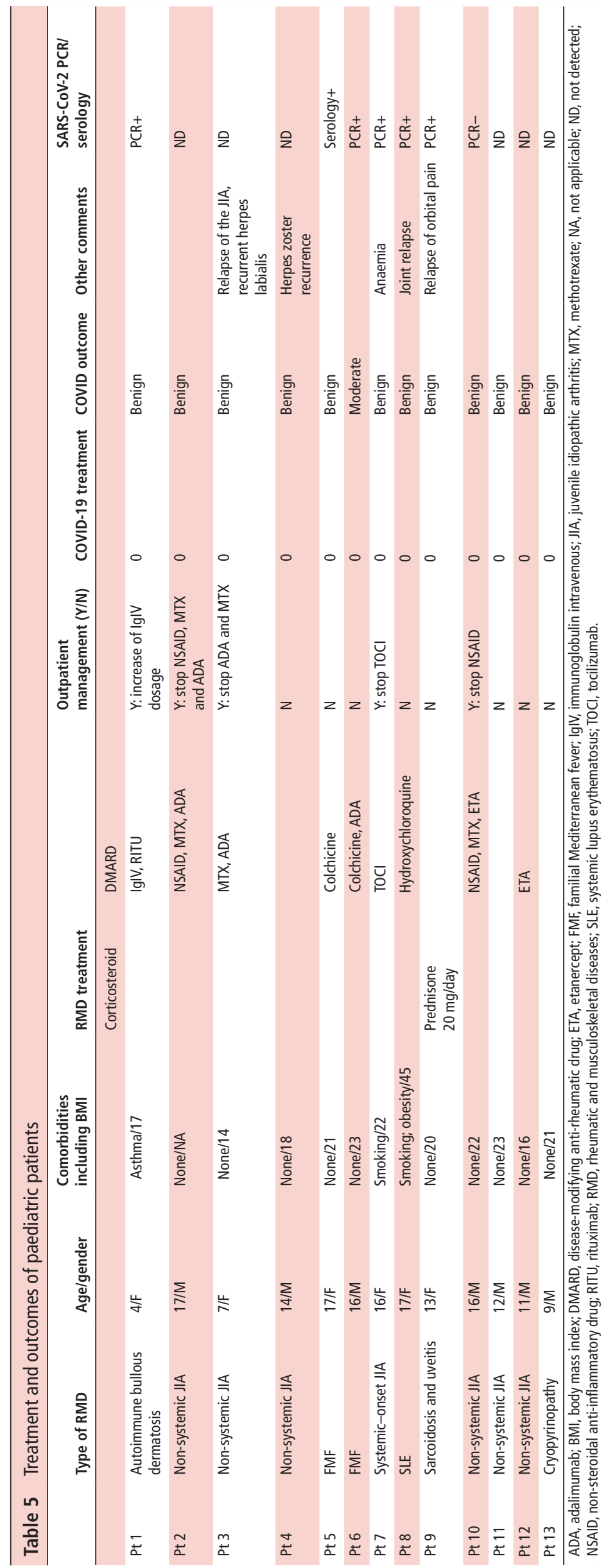


Table 6 Association between demographic and clinical characteristics and survival*

\begin{tabular}{|c|c|c|c|c|c|c|}
\hline & $\begin{array}{l}\text { Survivors } \\
(n=617)\end{array}$ & $\begin{array}{l}\text { Non-survivors } \\
(n=58)\end{array}$ & OR $(95 \% \mathrm{Cl}) \dagger$ & $P$ value & aOR $(95 \% \mathrm{Cl}) \dagger \ddagger$ & $P$ value \\
\hline Age§ (years) & & & & $<0.001$ & & $<0.001$ \\
\hline $18-54$ & $327(53.0)$ & $3(5.2)$ & 1.00 (ref.) & - & 1.00 (ref.) & - \\
\hline $55-64$ & $126(20.4)$ & $7(12.1)$ & $5.55(1.62-23.14)$ & 0.009 & $5.54(1.62-23.13)$ & 0.009 \\
\hline $65-74$ & $98(15.9)$ & $7(12.1)$ & $7.13(2.08-29.79)$ & 0.003 & $6.70(1.95-28.07)$ & 0.004 \\
\hline$\geq 75$ & $66(10.7)$ & $41(70.7)$ & $58.39(21.65-218.44)$ & $<0.001$ & $59.02(21.79-221.45)$ & $<0.001$ \\
\hline Mean \pm SD & $53.9 \pm 15.3$ & $76.6 \pm 12.6$ & & & & \\
\hline Female gender & $418(67.8)$ & $30(51.7)$ & $0.51(0.30-0.88)$ & 0.015 & $0.48(0.25-0.89)$ & 0.020 \\
\hline \multicolumn{7}{|l|}{ Comorbidities $q$} \\
\hline Respiratory disease (all) & $82(13.3)$ & $15(25.9)$ & $2.27(1.21-4.27)$ & 0.011 & $1.64(0.78-3.43)$ & 0.19 \\
\hline Interstitial lung disease & $18(2.9)$ & $8(13.8)$ & $5.31(2.20-12.81)$ & $<0.001$ & $3.82(1.27-11.49)$ & 0.017 \\
\hline COPD & $21(3.4)$ & $6(10.3)$ & $3.26(1.26-8.44)$ & 0.015 & $0.95(0.32-2.81)$ & 0.93 \\
\hline Asthma§ & $48(7.8)$ & $3(5.2)$ & $0.74(0.20-1.99)$ & 0.60 & $1.15(0.27-3.72)$ & 0.83 \\
\hline Cardiac disease (all) & $56(9.1)$ & $27(46.6)$ & $8.69(4.85-15.60)$ & $<0.001$ & $1.87(0.93-3.76)$ & 0.081 \\
\hline Coronary heart diseases & $41(6.7)$ & $25(43.1)$ & $10.61(5.77-19.49)$ & $<0.001$ & $2.18(1.05-4.53)$ & 0.037 \\
\hline Stroke & $19(3.1)$ & $6(10.3)$ & $3.62(1.39-9.46)$ & 0.009 & $1.52(0.51-4.56)$ & 0.46 \\
\hline Diabetes & $43(7.0)$ & $18(31.0)$ & $6.00(3.17-11.32)$ & $<0.001$ & $2.89(1.39-6.02)$ & 0.005 \\
\hline Obesity§ & & & & 0.053 & & 0.072 \\
\hline$<30$ & $419(77.3)$ & $33(66.0)$ & 1.00 (ref.) & - & 1.00 (ref.) & - \\
\hline $30-39.9$ & $108(19.9)$ & $13(26.0)$ & $1.56(0.78-2.97)$ & 0.19 & $1.95(0.88-4.18)$ & 0.093 \\
\hline$\geq 40$ & $15(2.8)$ & $4(8.0)$ & $3.64(1.07-10.29)$ & 0.026 & $3.77(0.86-15.09)$ & 0.070 \\
\hline Hypertension & $133(21.6)$ & $40(69.0)$ & $8.05(4.47-14.51)$ & $<0.001$ & $3.08(1.56-6.08)$ & 0.001 \\
\hline Cancer & $25(4.1)$ & $6(10.3)$ & $2.73(1.07-6.94)$ & 0.036 & $1.05(0.35-3.11)$ & 0.93 \\
\hline Chronic renal failure & $22(3.6)$ & $18(31.0)$ & $12.13(6.02-24.44)$ & $<0.001$ & $5.22(2.22-12.31)$ & $<0.001$ \\
\hline No. of patients with at least one comorbidity§ & $419(68.1)$ & $57(98.3)$ & $17.96(4.83-159.20)$ & $<0.001$ & $5.61(1.41-50.93)$ & 0.043 \\
\hline Disease history§ & & & & $<0.001$ & & 0.039 \\
\hline Chronic inflammatory arthritis & $427(69.2)$ & $25(43.1)$ & 1.00 (ref.) & - & 1.00 (ref.) & - \\
\hline Autoinflammatory diseases & $10(1.6)$ & $2(3.5)$ & $3.99(0.74-14.77)$ & 0.069 & $8.98(0.94-63.49)$ & 0.040 \\
\hline Vasculitis & $47(7.6)$ & $17(29.3)$ & $6.18(3.10-12.13)$ & $<0.001$ & $2.09(0.93-4.56)$ & 0.070 \\
\hline Systemic autoimmune diseases & $105(17.0)$ & $12(20.7)$ & $1.99(0.95-3.97)$ & 0.059 & $2.65(1.15-5.95)$ & 0.020 \\
\hline
\end{tabular}

Values are presented as frequency (percentage) unless otherwise indicated.

* Total number of survivors and non-survivors as presented excludes 19 patients whose status at day 21 was unknown at the time of data cut-off.

tORs were calculated for non-survivors, using survivors as reference.

$\ddagger$ Adjusted for age and sex.

$\S$ Penalised logistic regression (Firth method) was used due to low number of patients $(\mathrm{n}<5)$ in an analysed group.

१Two missing values for comorbidities except for obesity where 83 values are missing.

aOR, adjusted OR; COPD, chronic obstructive pulmonary disease.

combination with azithromycin, was the most used therapy, in $9.4 \%(65 / 694)$ of the patients. Routinely available antiviral therapies (ritonavir in combination with lopinavir or darunavir) were mainly administered to hospitalised patients $(10.5 \% ; 27 / 256)$. Use of anti-cytokine therapies (tocilizumab and anakinra) was rare $(0.6 \%)$ (online supplemental table 10$)$.

\section{DISCUSSION}

The current observational, multicentre, French cohort study examined the frequency of severe COVID-19 and factors associated with outcomes of SARS-CoV-2 infection in patients with iRMD. Though similar in objective to the Global Rheumatology Alliance Study, ${ }^{23}$ the present investigation analysed a larger patient population with iRMD from a single country and monitored individual data for at least 21 days after the first clinical sign of disease to confirm evolution of COVID-19 and retrieve missing data. While the results do not suggest causality, they inform on treatment options for COVID-19 in patients with iRMD.

Underlying immune dysfunction and treatment with immunosuppressive agents raised the possibility of an increased COVID-19 severity in patients with iRMD. In addition to age ( $\geq 75$ years), comorbidities such as chronic respiratory disease, cardiovascular disease, diabetes, hypertension, obesity (BMI $\geq 40 \mathrm{~kg} / \mathrm{m}^{2}$ ), and renal failure increased the risk for severe COVID-19, again reflecting the observed trend in subjects with non-rheumatic diseases. ${ }^{67}$ In the present study, death was observed more frequently in patients with iRMD, but this difference in the frequency of mortality did not reach statistical significance. Systemic autoimmune diseases (mainly systemic lupus, systemic sclerosis, Sjögren syndrome and myositis) and vasculitis were found to be independent factors for severe infection and/ or mortality, suggesting that a history of drug-induced immunosuppression may worsen the prognosis. ${ }^{2425}$ For autoinflammatory diseases, the results should be interpreted with caution due to the very low number of patients $(n=13)$. The use of higher continual doses of corticosteroids in these populations could have led to a poor outcome.

Within the current cohort, RMD treatments had a variable association with COVID-19 severity and mortality. We assessed the association of each medication separately because the number of different medications was too high to compare to a single reference group and also because of possible overlap between medications, such as conventional synthetic DMARD and biologic DMARD (bDMARD) combination therapy. Studies of patients with RMD and IBD showed that long-term corticosteroid use increased the risk of severe COVID-19 infection and death. ${ }^{811}$ In contrast, two other studies, $\mathrm{CHIC}^{26}$ and 
Table 7 Association between rheumatic disease treatments and survival*

\begin{tabular}{|c|c|c|c|c|c|c|}
\hline & $\begin{array}{l}\text { Survivors } \\
(n=617)\end{array}$ & $\begin{array}{l}\text { Non-survivors } \\
(n=58)\end{array}$ & OR $(95 \% \mathrm{Cl}) \dagger$ & $P$ value & aOR $(95 \% \mathrm{Cl}) \dagger \ddagger$ & $P$ value $\ddagger$ \\
\hline \multicolumn{7}{|l|}{ Rheumatic or inflammatory disease treatments§ } \\
\hline Corticosteroid & $172(27.9)$ & $39(68.4)$ & $5.59(3.11-10.05)$ & $<0.001$ & $2.64(1.36-5.12)$ & 0.004 \\
\hline Daily prednisone doses $\geq 10 \mathrm{mg}$ or equivalent & $50(29.4)$ & $21(53.8)$ & $2.80(1.38-5.70)$ & 0.005 & $2.91(1.28-6.59)$ & 0.011 \\
\hline NSAIDs & $73(11.9)$ & 0 & NA & NA & NA & NA \\
\hline Colchicine & $20(3.2)$ & $4(7.0)$ & $2.45(0.75-6.50)$ & 0.10 & $8.21(1.60-37.97)$ & 0.009 \\
\hline Hydroxychloroquineף & $52(8.4)$ & $2(3.5)$ & $0.48(0.10-1.47)$ & 0.28 & $0.93(0.16-3.55)$ & 0.92 \\
\hline Methotrexate & $237(38.5)$ & $12(21.1)$ & $0.43(0.22-0.82)$ & 0.011 & $0.34(0.16-0.70)$ & 0.003 \\
\hline Leflunomide & $27(4.4)$ & 0 & NA & NA & NA & NA \\
\hline Sulfasalazine & $9(1.5)$ & 0 & NA & NA & NA & NA \\
\hline Mycophenolate mofetil/mycophenolic acid & $14(2.3)$ & $2(3.5)$ & $1.87(0.36-6.32)$ & 0.38 & $14.20(2.26-70.24)$ & 0.002 \\
\hline Azathioprine & $8(1.3)$ & $1(1.8)$ & NA & NA & NA & NA \\
\hline IgIV & $6(1.0)$ & $1(1.8)$ & NA & NA & NA & NA \\
\hline \multicolumn{7}{|l|}{ Biologics } \\
\hline Anti-TNFq & $194(31.5)$ & $4(7.0)$ & $0.18(0.06-0.44)$ & $<0.001$ & $0.74(0.22-2.01)$ & 0.58 \\
\hline Anti-IL-6Rף & $25(4.1)$ & $1(1.8)$ & $0.62(0.07-2.43)$ & 0.58 & $0.50(0.05-2.38)$ & 0.47 \\
\hline Rituximab & $27(4.4)$ & $7(12.3)$ & $3.05(1.27-7.36)$ & 0.013 & $4.04(1.35-12.04)$ & 0.012 \\
\hline Anti-IL-17a & $25(4.1)$ & 0 & NA & NA & NA & NA \\
\hline Anti-IL-1 & $6(1.0)$ & $2(3.5)$ & NA & NA & NA & NA \\
\hline Abataceptๆ & $17(2.8)$ & $1(1.8)$ & $0.91(0.10-3.71)$ & 0.92 & $0.58(0.06-3.09)$ & 0.59 \\
\hline JAK inhibitorq & $18(2.9)$ & $2(3.5)$ & $1.46(0.29-4.77)$ & 0.59 & $1.36(0.23-5.61)$ & 0.71 \\
\hline Other biologic & $16(2.6)$ & 0 & NA & NA & NA & NA \\
\hline
\end{tabular}

Values are presented as frequency (percentage) unless otherwise indicated.

Not applicable (NA) when $<10 / 617$ patients or 0 non-survivors.

*Total number of survivors and non-survivors as presented excludes 19 patients whose status at day 21 was unknown at the time of data cut-off.

tORs were calculated for non-survivors, using survivors as reference.

$\ddagger$ Adjusted for age and sex.

$\S$ Two patients with missing information for treatments.

ๆPenalised logistic regression (Firth method) was used due to low number of patients $(n<5)$ in an analysed group.

aOR, adjusted OR; IgIV, immunoglobulin intravenous; IL, interleukin; NSAIDs, non-steroidal anti-inflammatory drugs; TNF, tumour necrosis factor.

RECOVERY, ${ }^{27}$ recently demonstrated that methylprednisolone $250 \mathrm{mg}$ or dexamethasone $6 \mathrm{mg}$ were beneficial when patients with COVID-19 develop a severe form (cytokine storm syndrome), respectively. These studies and ours suggest that the beneficial or aggravating effect of corticosteroids is a matter of timing. Conversely, anti-TNF $\alpha$ therapies were associated with a lower frequency of severe infection or mortality and also with less frequent hospitalisation. These findings are consistent with a previous study that found lower odds of hospitalisation with bDMARD/targeted synthetic DMARD monotherapy, driven largely by anti-TNF therapies. ${ }^{8}$ Of note, similar observations have been made outside the scope of SARS-CoV-2, suggesting a beneficial effect of bDMARDs on the risk of sepsis after serious infection or a fatal outcome. ${ }^{28}$ Methotrexate use significantly reduced mortality and was not associated with the risk of severe disease, yet we caution against causal inference regarding drug effects given significant potential for residual confounding, notably indication bias. Interestingly, IL-6 inhibitors did not appear to affect COVID-19 severity or related death in our study. However, the number of patients taking anti-IL-6 agents or JAK inhibitors was small and may have been insufficient to demonstrate other underlying effects. Likewise, the small number of patients treated with colchicine, mycophenolate mofetil, azathioprine, and rituximab (less than 10 patients with severe disease or death) does not allow for conclusions on a potential risk. Furthermore, potential indication bias exists since these drugs are mostly prescribed in patients with autoinflammatory, systemic autoimmune diseases, and vasculitis, all of which were associated with a higher frequency of severe infection in our cohort. Finally, as patients with active or very active iRMD tend to be more heavily medicated and we were unable to obtain information about disease activity, we cannot rule out that the higher frequencies identified with some treatments could be confounded by indication. To further explore these results, ancillary studies will be performed, with the potential merging of data with GRA and EULAR cohorts. Similarly, treatment with agents such as HCQ did not appear to have a positive impact on the frequency of severe disease or death. ${ }^{29}$ Our study shows that patients previously treated with HCQ can develop COVID-19, consistent with a report of severe COVID-19 in patients with lupus taking HCQ. ${ }^{30}$ We also collected information about the antiviral and immunomodulating therapies, notably HCQ, used by French clinicians to manage COVID-19. Our study is informative, but not built to inform on potential efficacy of antiviral and/ or immunomodulating therapies in COVID-19 management.

Despite communication to all French paediatric rheumatology centres, the RMD COVID-19 cohort contained only 13 children that displayed minor symptoms. This strengthens the previous reports on the lack of severe COVID-19 in children with rheumatic diseases. ${ }^{31}$ In addition, no iRMD COVID-19 paediatric case fulfilled the criteria for the recently recognised SARS-CoV2-related paediatric inflammatory multisystem syndrome, a post-infection disease. ${ }^{32}$ This latter observation could suggest that inflammatory diseases in children are not a risk factor for this specific syndrome.

There are several limitations to the current study. The first limitation is that no formal sample size calculation was performed for primary and secondary objectives and we cannot exclude a lack of adequate statistical power to detect significant differences. Moreover, due to the small number of events, multivariate analysis was not performed for death. The mortality rate in our cohort $(8.3 \%)$ was similar to a previous report $(7.2 \%) .^{23}$ 
Though the current study analysed a large patient population assessed within a single country, the impact of selection bias on the observed frequency of death cannot be dismissed. During the beginning phases of the pandemic, immense pressure on the French medical system precluded PCR testing in all patients and focused confirmatory efforts on subjects with the most severe disease. Despite this shortcoming of unconfirmed diagnosis, our cohort includes a substantial ambulatory subgroup with mild disease. Since the French RMD COVID-19 cohort is an observational multicentre cohort study, we cannot rule out that all highly suspected/confirmed symptomatic patients with COVID-19 were enrolled by comparison to LICORNE registry of all suspected/confirmed patients with COVID-19 admitted at the Lille University Hospital. A potential selection bias in favour of inclusion of more patients with severe iRMD COVID-19 could explain the observed non-significant higher mortality in hospitalised population with iRMD compared with a cohort with non-iRMD. Furthermore, the care provided for patients of LICORNE registry may be different than that delivered to patients from the French iRMD COVID-19 cohort. Indeed, even if all patients come from the same country, discrepancies could exist in the care delivered to patients across the country, with respect to the type of hospital (secondary or tertiary care, academic, non-academic), resources available (including ICU beds and ventilators), the availability of alternative care and palliative care facilities, and the treatment approach itself, especially at the beginning of the pandemic. Moreover, within countries, another variable is the differential effect of the pandemic over time across the country. Nevertheless, an increased risk of death has recently been shown in 19 patients with RA/systemic lupus erythematosus/psoriasis-COVID-19 with an adjusted HR of $1.19(1.11-1.27){ }^{6}$

In conclusion, the present study assesses the frequency of mild, moderate and severe COVID-19 and mortality in a large cohort of patients with rheumatic, autoinflammatory and autoimmune diseases being treated in France. In addition to monitoring the evolution of COVID-19 severity and outcomes, we confirmed the impact of comorbidities within the population with iRMD and generated preliminary data on the effects of anti-rheumatic therapies on disease prognosis following SARS-CoV-2 infection. We observed a higher frequency of death in the hospitalised population with iRMD compared with a cohort with non-iRMD from hospitalised patients with similar comorbidities, although the difference did not reach statistical significance. Furthers studies are warranted to confirm these results.

Acknowledgements We thank the scientific committee of the consortium for this large undertaking and regular discussion: $E H$, Alexandre Belot, Hélène Maillard, Sophie Georgin-Lavialle, Christophe Richez for FAI ${ }^{2} \mathrm{R}$; Thierry Thomas for the SFR; Jacques Pouchot and Patrice Cacoub for the SNFMI; Aurélia Carbasse and Ulrich Meinzer for the SOFREMIP; Christophe Richez for the CRI; Bruno Fautrel for IMIDIATE. We thank Samira Plassart for protocol design input and Laurent Schwarb (Promoter Representative of the Direction de la Recherche et de I'Innovation, CHU Lille) for managing all regulatory aspects. Muriel Herasse, Samira Plassard, Virginie Lucas, Sarahe Dehimat, Mélanie Romier, Alexandra Willems, Fanny Fernandes and Anna Kabala played a major role in collecting the missing data of the cohort. We thank Elodie Drumez, Julien Labreuche, Alain Duhamel (biostatistician, CHU-Lille) and Thomas Barnetche (project manager, CHU-Bordeaux), for the statistical analysis and for help in the preparation of this manuscript. Charlotte Lejeune, Alexandra Willems, Justine Simoens and Muriel Herasse contributed to the regular communication and information provided to the French medical community to encourage the inclusion of new cases. The Lille COVID-19 Research Network (LICORNE) wishes to acknowledge the contribution of the residents, medical students, nursing teams, lab technicians and clinical research associates in the midst of the SARS-COV-2 pandemic. We also thank the pro-bono support of SANOÏA Digital CRO team who provided outstanding eCRF, agile data visualisation and extensive project support. JetPub Scientific Communications assisted in the preparation of this manuscript, in accordance with Good Publication Practice (GPP3) guidelines.
Collaborators $\mathrm{FAI}^{2} \mathrm{R} / \mathrm{SFR} / \mathrm{SNFMI/SOFREMIP/CRI/IMIDIATE} \mathrm{consortium} \mathrm{and}$ contributors: Aeschlimann Florence, Paris; Ait-Abdallah Nassim, Paris; Albert Jean-David, Rennes; Alcais Didier, Le Havre; Allanore Yannick, Paris; Amador-Borreiro Blanca, Paris; Amoura Zahir, Paris; Andre Emma, Paris; Arlet Jean-Benoît, Paris; Arnaud Laurent, Strasbourg; Arniaud Denis, Marseille; Arty-Hue Herliette, Gap; Atlan Lucie, Amboise; Audoin-Pajot Christine, Toulouse; Audren Victor, Paris; Avouac Jérôme, Paris; Bach-Bunner Maxime, Colmar; Bacquet-Deschryver Hélène, Dieppe; Bader-Meunier Brigitte, Paris; Balandraud Nathalie, Marseille; Balblanc Jean-Charles, Trevenans; Bally Stéphane, Chambery; Banal Frédéric, Saint-Mande; Banneville Béatrice, Paris; Barnetche Thomas, Bordeaux; Barrelet Audre, Jossigny; Basch André, Caluire-Et-Cuire; Baumier Vincent, Clermont-Ferrand; Bayer Guillaume, Quincy-SousSenart; Bayle Sophie, Avignon; Belin Véronique, Thonon-Les-Bains; Belkhir Rakiba, Kremlin-Bicetre; Benainous Ruben, Bobigny; Belot Alexandre, Lyon; Benammar Mohammed, Saint-Quentin; Benhamou Mathilde, Versailles; Benhamou Ygal, Rouen; Benmansour Ahmed, Chateauroux; Bennet Pascal, Bois-Guillaume; Bernoux-Manat Brigitte, Rennes; Berthoux Emilie, Lyon; Bertolini Ewa, Annecy; Bisson-Vaivre Aurélia, Castres; Blaison Gilles, Colmar; Bolla Gilles, Cannes; Bonidan Olivier, Agen; Bonnet Christine, Limoges; Borie Raphaël, Paris; Boudou Laurence, Saint-Chamond; Bouhour Françoise, Bron; Bouiller Kévin, Besancon; Bouldoires Bastien, Colmar; Boussoualim Karima, Saint-Priest-En-Jarez; Bouvard Eric, Paris; Brondino Regine, PennesMirabeau; Buchlin Pierre, Mulhouse; Cacoub Patrice, Paris; Carteni Maurizio, Saint-Pierre-De-Coutances; Carbasse Aurélia, Montpellier; Castel Brice, Tarbes; Cathebras Pascal, Saint-Priest-En-Jarez; Caumont Hervé, Troyes; Celant Annalisa, Metz; Chaigne Benjamin, Paris; Chaillous Benoît, Herbiers; Champy Romuald, Ecuelles; Charcot Agnès, Paris; Charles Pierre, Paris; Charlot-Lambrecht Isabelle, Reims; Charpin Caroline, Marseille; Chatelus Emmanuel, Strasbourg; Chaudier Bernard, Marseille; Chazerain Pascal, Paris; Chertok Pascale, Argenteuil; Chevalier Xavier, Creteil; Chevreau Maxime, Aix-Les-Bains; Chotard Emilie, Paris; Chu Miow Lin Delphine, Tours; Claudepierre Pascal, Creteil; Clavel Gaëlle, Paris; Clavel-Osorio Cyril, Saint-Martin; Cohen Fleur, Paris; Cohen Gregory, Avignon; Colette-Cedoz Marie-Eve, Bourgoin-Jallieu; Collercandy Nived, Tours; Colombey Antoine, Saint-Nazaire; Comarmond Chloé, Paris; Combe Bernard, Montpellier; Comparon Céline, Bobigny; Constant Elodie, Valence; Corre Clémence, Vannes; Costedoat-Chalumeau Nathalie, Paris; Couret Marie, Bourg-En-Bresse; Courvoisier Natacha, Nogent-Sur-Marne; Coury-Lucas Fabienne, Pierre-Benite; Coutarel Cécile, Clermont-Ferrand; Coutier Fabrice, Vesoul; Damade Richard, Chartres; Daver-Malaterre Laurence, Marseille; Dehimat Sarahe, Lille; Delahousse Michel, Suresnes; Descamps Elise, Paris; Deslandre Chantal, Paris; Desmurs Marie, Mulhouse; Despaux Jacques, Montelimar; Desplats Marie, Lambersart; Detree Frédérick, Reims; Devauchelle-Pensec Valérie, Brest; Devaux Mathilde, Poissy; Dhote Robin, Bobigny; Dieude Philippe, Paris; Dieudonne Yannick, Strasbourg; Diot Elisabeth, Tours; Direz Guillaume, Le Mans; Djeddi Djamal-Dine, Amiens; Domont Fanny, Paris; Drouet Béatrice, Pau; Drumez Elodie, Lille; Duc Catherine, Romans-Sur-Isere; Ducornet Angélique, Saint Brieuc; Dufauret-Lombard Carine, Limoges; Duhamel Alain, Lille; Dumaine Cécile, Paris; Dumel Anne-Elisabeth, Cernay; Durand Géraldine, Poitiers; Duret Pierre-Marie, Colmar; Ebbo Mikaël, Marseille; Ebstein Esther, Paris; Economu-Dubosc Andra, Sucy-En-Brie; El Mahou Soumaya, Tourcoing; Euvrard Romain, Bourg-En-Bresse; Evon Philippe, Bar-Le-Duc; Fabre Sylvie, Montpellier; Fauconier Marion, Reims; Fautrel Bruno, Paris; Fechtenbaum Jacques, Pantin; Felten Renaud, Strasbourg; Fernandes Fanny, Paris; Ferreira-Maldent Nicole, Tours; Feurer Elodie, Lyon; Fichet Amandine, Trevenans; Flaisler Françoise, Nimes; Flipo René-Marc, Lille; Florens Nans, Lyon; Foltz Violaine, Paris; Fontanges Elisabeth, Lyon; Foret Jennifer, Dax; Fougerousse Anne-Claire, Saint-Mande; Fouque-Aubert Anne, Lyon; Foutrier-Morello Catherine, Plan-De-Cuques; Francois-Pradier Hélène, Paris; Frantzen Léa, Mulhouse; Fritz Pierre, Paris; Froissart Antoine, Creteil; Fulpin Jean, Toulon; Fuzibet Piera, Orleans; Gaches Francis, Toulouse; Gagneux-Lemoussu Laurence, Reims; Gahier Penhoat Mélanie, Saint-Nazaire; Galland Joris, Paris; Gandjbakhch Frédérique, Paris; Garnier Nicole Plaisance-Du-Touch; Garraud Thomas, Nantes; Garrot Jean-François, Semur-EnAuxois; Gastaldi Romain, Grenoble; Gaud-Listrat Véronique, Saint-Michel-Sur-Orge; Gauthier-Prieur Maud, Louviers; Georgescu Dana, Vienne; Georgin-Lavialle Sophie, Paris; Gerard Nathalie, Dijon; Gervais Elisabeth, Poitiers; Gibert Christelle, Valence; Gibert Eric, Paris; Gill Ghislaine, Paris; Gillard Jérôme, Lons-Le-Saunier; Gilson Mélanie, Grenoble; Gimonnet Pauline, Epernay; Giraudet-Le Quintrec Jeanine-Sophie, Paris; Giraud-Morelet Aude, Ecully; Glace Baptiste, Vichy; Glanowski Camille, Saint-Mande; Godeau Bertrand, Creteil; Gombert Bruno, La Rochelle; Gonnet-Gracia Camille, La Rochelle; Goulenok Tiphaine, Paris; Goupille Philippe, Tours; Gourmelen Olivier, Aix-Les-Bains; Govindaraju-Audouard Sophie, Vesoul; Grados Franck, Amiens; Grardel Bruno, Arras; Grasland Anne, Colombes; Grateau Gilles, Paris; Groza Monica, Colmar; Guillaud Constance, Creteil; Guillaume Séverine, Kremlin-Bicetre; Guillot Xavier, Saint-Denis; Guilpain Philippe, Montpellier; Gury Aline, Angers; Guyot Marie-Hélène, Roubaix; Hachulla Eric, Lille; Hacquard-Bouder Cécile, Yvetot; Havard Marie-Noelle, Argenteuil; Hellier Jean-Pierre, Arles; Hennequin Pascal, Epinal; Henriot Basile, Dinan; Henry Julien, Kremlin-Bicetre; Hentgen Véronique, Le Chesnay; Hermet Marion, Vichy; Herasse Muriel, Lyon; Hie Miguel, Paris; Hittinger-Roux Ambre, Reims; Hudry Christophe, Paris; Huguenel Serge, Sarrebourg; Jaccard Clara, ClermontFerrand; Jacquemier Jean-Michel, Cornebarrieu; Jamard Bénédicte, Toulouse; Jan Catherine, Bar-Le-Duc; Jean Sylvie, Rennes; Jouvray Mathieu, Arras; Juge PierreAntoine, Paris; Juillard Laurent, Lyon; Jullien Denis, Lyon; Kabala Anna, Bordeaux; 
Kabchou Abdelkrim, Vichy; Karkowski Ludovic, Lyon; Karman Françoise, PontaultCombault; Kemiche Farid, Pontoise; Keraen Jérémy, Quimper; Kone-Paut Isabelle, Kremlin-Bicetre; Koreichi Abdeldajallil, Lorient; La Batide Alanore Sylvain, Paris; Lafforgue Pierre, Marseille; Lahalle Sophie, Paris; Langlois Vincent, Le Havre; Lanot Sylvain, Alencon; Lanteri Aurélia, Antibes; Larbre Jean-Paul, Pierre-Benite; Latourte Augustin, Paris; Lavigne Christian, Angers; Le Guen Guegan Sophie, Contamine-SurArve; Le Guenno Guillaume, Clermont-Ferrand; Lebrun Agnès, Paris; Ledoult Emmanuel, Tourcoing; Legoupil Nathalie, Paris; Legrand Erick, Angers; Lejeune Charlotte, Lille; Leloire Olivier, Ronchin; Leroux Christophe, Dreux; Leroy Rémi, Dunkerque; Leturca Tifenn, Paris; Liote Frédéric, Paris; Lohse Anne, Trevenans; Lucas Virginie, Lille; Madelon Aurélie, Grenoble; Mahevas Matthieu, Creteil; Maillard Hélène, Lille; Maillet Thibault, Macon; Malochet-Guinamand Sandrine, ClermontFerrand; Mangon Quentin, Aurillac; Marchou-Lopez Sylvie, Crolles; Margarit Nathalie, Portet-Sur-Garonne; Marhadour Thierry, Brest; Maria Alexandre, Montpellier; Mariette Xavier, Kremlin-Bicetre; Marotte Hubert, Saint-Priest-En-Jarez; Mathian Alexis, Paris; Maurier François, Metz; Maury Frédéric, Beuvry; Mazet-Guillaume Betty, Angers; Mazouyez Arnaud, Contamine-Sur-Arve; Mazyad Hassan, Poissy; Mehsen-Cetre Nadia, Bordeaux; Meinzer Ulrich, Paris; Mekinian Arsène, Paris; Melki Isabelle, Paris; Messer Laurent, Colmar; Michaud Martin, Toulouse; Michon Mathilde, Courbevoie; Milesi-Lecat Anne-Marie, Vichy; Molto Anna, Paris; Moly Marie, Montpellier; Moranne Olivier, Nimes; Morel Gautier, Valenciennes; Morel Hugo, Dijon; Morel Jacques, Montpellier; Morin Franck, Saint-Pierre-De-Coutances; Moulinier Laurence, Paris; Moulis Guillaume, Toulouse; Moura Bertrand, Paris; Nguyen Minh, Paris; NicolasVullierme Sabine, Chatillon; Nielly Hubert, Saint-Mande; Nocturne Gaétane, Kremlin-Bicetre; Ollagnon Henri-Olivier, Villeurbanne; Pacaud-Vitoux Isabelle, Guilherand-Granges; Paris Caroline, Marseille; Parrot Antoine, Paris; Pascart Tristan Lille; Pascaud-Mansour Yasmina, Angers; Paulin Lætitia, Bourgoin-Jallieu; Pavy Stephan, Kremlin-Bicetre; Perard Laurent, Lyon; Pers Yves-Marie, Montpellier; Pertuiset Edouard, Pontoise; Pha Micheline, Paris; Pham Thao, Marseille; Pichon Maud, Argenteuil Pizana Gabrielle, Fougeres; Poix Elsa, Quint-Fonsegrives; Portier Agnès, Paris; Pouchot Jacques, Paris; Poulet Antoine, Marseille; Plassard Samira, Lyon; Pugnet Grégory, Toulouse; Puyraimond-Zemmour Déborah, Paris; Quartier-Dit-Maire Pierre, Paris; Quenet Marion, Saint-Brieuc; Remy Philippe, Creteil; Renard Myriam, Aix-Les-Bains; Rene Jessica, Tours; Revuz Sabine, Metz; Richard-Colmant Gaëlle, Lyon; Richez Christophe, Bordeaux; Riviere Etienne, Bordeaux; Riviere Sébastien, Paris; Robin Sophie, Elbeuf; Rohmer Julien, Suresnes; Roitg Isabelle, Perpignan; Romier Mélanie, Lyon; Rolland Michel, Saint-Etienne; Roriz Mélanie, Agen; Rossi Linda, Kremlin-Bicetre; Roth Olivier, Marseille; Rouidi Sid-Ahmed, Dreux; Roumier Mathilde, Suresnes; Rousiere Mickaël, Paris; Rousselin Clémentine, Valenciennes; Roux Christian, Nice; Roux Fabienne, Paris; Roux Marielle, Bourgoin-Jallieu; Roux Nicolas, Metz; Rouzaud Diane, Paris; Rozenberg Sylvie, Paris; Sacco Isabelle, Paris; Sadji Fatiha, Poissy; Sailler Laurent, Toulouse; Salliot Carine, Orleans; Salmon Jean-Hugues, Reims; Schmidt Jean, Amiens; Seguier Julie, Marseille; Sellam Jérémie, Paris; Senbel Eric, Marseille; Sene Thomas, Paris; Senet Patricia, Paris; Seror Raphaële, Kremlin-Bicetre; Servettaz Amélie, Reims; Seve Pascal, Lyon; Sicaud Aurélie, Le Pont-De-Beauvoisin; Smets Perrine, Clermont-Ferrand; Sobanski Vincent, Lille; Sordet Christelle, Strasbourg; Sornay-Rendu Elisabeth, La Tour-Du-Pin; Souchaud-Debouverie Odile, Poitiers; Sparsa Lætitia, Mulhouse; Steib Sarah, Aubagne; Strotz Victor, Antony; Szafors Paulina, Montpellier; Taffignon-Clave Séverine, Ecully; Simoens Justine, Lille; Tenenbaum Nora, Paris; Thomachot Benoît, Gardanne; Thomas Thierry, Saint-PriestEn-Jarez; Tieulie Nathalie, Nice; Tison Alice, Bordeaux; Toussirot Eric, Besancon; Trefond Ludovic, Clermont-Ferrand; Trijau Sophie, Marseille; Trouillier Sébastien, Aurillac; Truchetet, Marie-Elise, Bordeaux; Veillard Eric, Saint-Malo; Veillon Laurent, Orleans; Vial Guillaume, Bordeaux; Veillard Eric, Saint-Malo; Veillon Laurent, Orléans; Vial Guillaume, Bordeaux, Viallard Jean-François, Bordeaux; Victor Judith, Bordeaux; Vidon Claire, Aix-Les-Bains; Vidon Mathias, Creteil; Vigne Camille, Pierre-Benite; Virone Alexandre, Kremlin-Bicetre; Warzocha Ursula, Bobigny; Wendling Daniel, Besancon; Werle Claude, Haguenau; Willems Alexandra, Lille; Wisniewski Michel, Saint-Amand-Les-Eaux; Woessner Juliette, Avignon; Xerri-Campano Bernadette, Saint-Maur-Des-Fosses.

Contributors On behalf of the FAI²R/SFR/SNFMI/SOFREMIP/CRI/IMIDIATE consortium and contributors, FAI ${ }^{2}$ R: Filière des maladies Auto-Immunes et Autoinflammatoires Rares; SFR: Société Française de Rhumatologie; SNFMI: Société Nationale Française de Médecine Interne; SOFREMIP: Société Francophone pour I'Etude des Rhumatismes et Maladies Inflammatoires Pédiatriques; CRI: Club Rhumatismes et Inflammation; IMIDIATE: Immune-Mediated Inflammatory Disease Alliance for Translational and Clinical Research Network.

Funding This study was not supported by research funding but FAI ${ }^{2} R$ is funded by "le ministère des solidarités et de la santé".

Competing interests None declared.

Patient consent for publication Not required.

Provenance and peer review Not commissioned; externally peer reviewed.

Data availability statement Data are available upon reasonable request. All relevant anonymised patient-level data are available upon reasonable request to the corresponding author.
Supplemental material This content has been supplied by the author(s). It has not been vetted by BMJ Publishing Group Limited (BMJ) and may not have been peer-reviewed. Any opinions or recommendations discussed are solely those of the author(s) and are not endorsed by BMJ. BMJ disclaims all liability and responsibility arising from any reliance placed on the content. Where the content includes any translated material, BMJ does not warrant the accuracy and reliability of the translations (including but not limited to local regulations, clinical guidelines, terminology, drug names and drug dosages), and is not responsible for any error and/or omissions arising from translation and adaptation or otherwise.

Open access This is an open access article distributed in accordance with the Creative Commons Attribution Non Commercial (CC BY-NC 4.0) license, which permits others to distribute, remix, adapt, build upon this work non-commercially, and license their derivative works on different terms, provided the original work is properly cited, appropriate credit is given, any changes made indicated, and the use is non-commercial. See: http://creativecommons.org/licenses/by-nc/4.0/.

\section{REFERENCES}

1 Luo P, Liu Y, Qiu L, et al. Tocilizumab treatment in COVID-19: a single center experience. J Med Viro/2020

2 Verity R, Okell LC, Dorigatti I, et al. Estimates of the severity of coronavirus disease 2019: a model-based analysis. Lancet Infect Dis 2020;20:669-77.

3 Moatti J-P. The French response to COVID-19: intrinsic difficulties at the interface of science, public health, and policy. Lancet Public Health 2020;5:e255.

4 Nirasay S. Bilan en direct sur l'évolution du coronavirus (Covid-19) en France et dans le monde - Auteur du tableau de bord. Available: https://www.bilancoronavirus.fr/ [Accessed 6 Aug 2020].

5 Salje H, Tran Kiem C, Lefrancq N, et al. Estimating the burden of SARS-CoV-2 in France. Science 2020:eabc3517.

6 Williamson EJ, Walker AJ, Bhaskaran K, et al. OpenSAFELY: factors associated with COVID-19 death in 17 million patients. Nature2020

7 D'Silva KM, Serling-Boyd N, Wallwork R, et al. Clinical characteristics and outcomes of patients with coronavirus disease 2019 (COVID-19) and rheumatic disease: a comparative cohort study from a US 'hot spot'. Ann Rheum Dis 2020;79:1156-62.

8 Gianfrancesco MA, Hyrich KL, Gossec L, et al. Rheumatic disease and COVID-19: initial data from the COVID-19 global rheumatology alliance provider registries. Lancet Rheumatol 2020;2:e250-e253.

9 Sanchez-Piedra C, Diaz-Torne C, Manero J, et al. Clinical features and outcomes of COVID-19 in patients with rheumatic diseases treated with biological and synthetic targeted therapies. Ann Rheum Dis 2020;79:988-90.

10 Haberman RH, Castillo R, Chen A, et al. COVID-19 in patients with inflammatory arthritis: a prospective study on the effects of comorbidities and DMARDs on clinical outcomes. Arthritis Rheumatol 2020. doi:10.1002/art.41456. [Epub ahead of print: $28 \mathrm{Jul} 2020]$

11 Brenner EJ, Ungaro RC, Gearry RB, et al. Corticosteroids, but not TNF antagonists, are associated with adverse COVID-19 outcomes in patients with inflammatory bowel diseases: results from an international registry. Gastroenterology 2020;159:481-91.

12 Brito CA, Paiva JG, Pimentel FN. COVID-19 in patients with rheumatological diseases treated with anti-TNF. Ann Rheum Dis 2020:doi:10.1136/annrheumdis-2020-218171. [Epub ahead of print: 16 June 2020].

13 Landewé RB, Machado PM, Kroon F, et al. EULAR provisional recommendations for the management of rheumatic and musculoskeletal diseases in the context of SARS CoV-2. Ann Rheum Dis 2020:79:851-8.

14 Legifrance. Journal officiel 'Lois et Décrets' - JORF nº160 du 13 juillet 2018. Available: https://www.legifrance.gouv.fr/affichJ0.do?idJO= JORFCONT000037186583 [Accessed 10 Jun 2020].

15 CNIL. Recherches n'impliquant pas la personne humaine études et évaluations dans le domaine de la santé Méthodologie de référence MR-004. Available: https://www.cnil. $\mathrm{fr} / \mathrm{fr} / \mathrm{declaration} / \mathrm{mr}$-004-recherches-nimpliquant-pas-la-personne-humaine-etudes-etevaluations-dans-le [Accessed 10 Jun 2020].

16 Buuren Svan, Groothuis-Oudshoorn K. mice : Multivariate imputation by chained equations in R. J Stat Softw 2011;45:1-67.

17 Toutenburg H, Rubin DB. Multiple imputation for nonresponse in surveys. Stat Pap 1990;31:180.

18 Gandhi RT, Lynch JB, del Rio C. Mild or moderate Covid-19. N Eng/ J Med 2020

19 Berlin DA, Gulick RM, Martinez FJ. Severe Covid-19. N Eng/ J Med 2020. doi:10.1056 NEJMcp2009575. [Epub ahead of print: 15 May 2020].

20 Austin PC. A comparison of 12 algorithms for matching on the propensity score. Stat Med 2014;33:1057-69.

21 Austin PC. Optimal caliper widths for propensity-score matching when estimating differences in means and differences in proportions in observational studies. Pharm Stat 2011;10:150-61.

22 Austin PC. Balance diagnostics for comparing the distribution of baseline covariates between treatment groups in propensity-score matched samples. Stat Med 2009:28:3083-107

23 Gianfrancesco MA, Hyrich KL, Gossec L, et al. Rheumatic disease and COVID-19: initial data from the COVID-19 global rheumatology alliance provider registries. Lancet Rheumatol 2020;2:e250-3. 
24 Tomelleri A, Sartorelli S, Campochiaro C, et al. Impact of COVID-19 pandemic on patients with large-vessel vasculitis in Italy: a monocentric survey. Ann Rheum Dis 2020;79:1252-3.

25 Menter T, Haslbauer JD, Nienhold R, et al. Postmortem examination of COVID-19 patients reveals diffuse alveolar damage with severe capillary congestion and variegated findings in lungs and other organs suggesting vascular dysfunction. Histopathology 2020 doi:10.1111/his.14134. [Epub ahead of print: 04 May 2020].

26 Ramiro S, Mostard RLM, Magro-Checa C, et al. Historically controlled comparison of glucocorticoids with or without tocilizumab versus supportive care only in patients with COVID-19-associated cytokine storm syndrome: results of the chiC study. Ann Rheum Dis 2020;79:1143-51.

27 RECOVERY Collaborative Group, Horby P, Lim WS, et al. Dexamethasone in Hospitalized Patients with Covid-19 - Preliminary Report. N Engl J Med 2020. doi:10.1056/NEJMoa2021436. [Epub ahead of print: 17 Jul 2020].
28 Richter A, Listing J, Schneider M, et al. Impact of treatment with biologic DMARDs on the risk of sepsis or mortality after serious infection in patients with rheumatoid arthritis. Ann Rheum Dis 2016;75:1667-73.

29 Mahévas M, Tran V-T, Roumier M, et al. Clinical efficacy of hydroxychloroquine in patients with covid-19 pneumonia who require oxygen: observational comparative study using routine care data. BMJ 2020;369:m1844.

30 Mathian A, Mahevas M, Rohmer J, et al. Clinical course of coronavirus disease 2019 (COVID-19) in a series of 17 patients with systemic lupus erythematosus under longterm treatment with hydroxychloroquine. Ann Rheum Dis 2020;79:837-9.

31 Filocamo G, Minoia F, Carbogno S, et al. Absence of severe complications from SARSCoV-2 infection in children with rheumatic diseases treated with biologic drugs. J Rheumato/ 2020. doi:10.3899/jrheum.200483. [Epub ahead of print: 25 Apr 2020]

32 Belot A, Antona D, Renolleau S, et al. SARS-CoV-2-related paediatric inflammatory multisystem syndrome, an epidemiological study, France, 1 March to 17 may 2020. Eurosurveillance 2020;25:2001010. 